\title{
Grundtvig-Selskabet af 8. september 1947: Årsberetning 2007
}

\section{Af Peter Balslev-Clausen}

Grundtvig-Selskabets årsmøde 2006 blev afholdt fredag den 17. november $2006 \mathrm{kl} .15 .30 \mathrm{i}$ Vartov. Som årsmødets dirigent blev valgt Peter Neergaard Jessen. Til styrelsen blev Jørgen I. Jensen og Peter Balslev-Clausen genvalgt, til forretningsudvalget blev Peter BalslevClausen genvalgt. Forretningsudvalget har derefter konstitueret sig med Peter Balslev-Clausen som formand, Flemming LundgreenNielsen som næstformand, Erik Jakob Petersen som kasserer, Jens Holger Schjørring som ansvarshavende redaktør for GrundtvigStudier, Kim Arne Pedersen som sekretær og Christian Thodberg som menigt medlem. I forbindelse med årsmødet gav Kim Arne Pedersen en redegørelse for sit arbejde med en gennemgang af Grundtvigs trykte tekster $\mathrm{i}$ forbindelse med forarbejderne til en digitaliseret udgave af Grundtvigs trykte forfatterskab.

På årsmødet 2006 blev der som punkt 4 på dagsordenen vedtaget nye vedtægter, der som bilag er vedlagt den trykte årsberetning. Ifølge de nye vedtægter skifter forretningsudvalget navn til Selskabets styrelse, der vil bestå af 5 medlemmer valgt for 5 år. Den hidtidige styrelse skifter navn til Repræsentantskab. Repræsentantskabet består af 20 medlemmer, der er på valg hvert 5. år. Første valg til den nye styrelse og det nye forretningsudvalg vil finde sted på det ordinære årsmøde 2007.

Forretningsudvalget har holdt møde den 26. marts 2007, hvor især Grundtvig-Studier 2007 og det igangværende udredningsarbejde forud for en digitalisering af Grundtvigs trykte forfatterskab blev drøftet.

Den norske afdeling af Grundtvig-Selskabet fortsætter sit virke med Synnøve Heggem som formand.

2007-årgangen af Grundtvig-Selskabets årbog Grundtvig-Studier, der redigeres af Jens Holger Schjørring (ansvarshavende redaktør), Flemming Lundgreen-Nielsen, Kim Arne Pedersen og S. A. J. Bradley, vil udkomme i løbet af efteråret.

På Center for Grundtvigstudier ved Aarhus Universitet, der ledes af Jens Holger Schjørring som centerleder og Ulrik Overgaard som daglig medarbejder, er en række forskningsprojekter i gang. Regner Birkelund undersøger Grundtvigs frihedsbegreb og dets virkningshistorie, Thorkild Lyby har videreført og afsluttet Claus Bjørns undersøgelse af Grundtvigs politiske virke med en udgivelse "Grundtvig som politiker" i Grundtvig-Selskabets skriftserie, Harry 
Haue viderefører Vagn Wåhlins arbejde med de folkelige bevægelser, der i nær fremtid fører til en udgivelse, Jette Holm, Elisabeth A. Glenthøj og Christian Thodberg fortsætter afskrift og udgivelse af Grundtvigs prædikener fra 1840'erne, hvoraf nu yderligere 4 bind med prædikener fra årene 1842-45 er udkommet, og Uffe Jonas er midt i et studie med titlen "Kvindeevangeliet: Om Grundtvigs mandebilleder og kvindesyn". Anders Holm har netop (31. august 2007) forsvaret sin ph.d.-afhandling om "To samtidige. En historisk-systematisk undersøgelse af Kierkegaards og Grundtvigs kritik af hinanden", Ulrik Overgaard skal i løbet af kort tid forsvare sin ph.d.-afhandling om den grundtvig-koldske grundskolepædagogik i dens relation til kristen livsforståelse. Dertil kommer, at første bind af S. A. J. Bradley's oversættelse af udvalgte tekster af og om Grundtvig står foran sin udgivelse. I januar i år blev der i Calcutta i Indien afholdt en konference om voksenundervisning og den grundtvigske inspiration i samarbejde mellem Center for Grundtvigstudier og professor Asoke Bhattacharya, Adult and Continuing Education and Extension Centre på Jadavpur University. Internationalt samarbejder Center for Grundtvigstudier med Grundtviginstitutet ved Göteborgs Universitet.

Det århusianske Grundtvigcenters samarbejdspartner i København, Grundtvig-Akademiet i Vartov, gennemførte januar-februar 2007 en møderække med overskriften "Kristendommen - den bedste religion?" Indledere var Hans Hauge, Anne Braad, Niels Thomsen, Anders Gadegaard, Elof Westergaard, Niels Henrik Arendt, Povl Götke og Sørine Gotfredsen.

Mødemæssigt har året været præget af den række af seminarer, der har været afholdt for at orientere om den digitale udgave af Grundtvigs trykte forfatterskab, som Center for Grundtvigstudier ved Aarhus Universitet og Grundtvig-Akademiet har taget initiativ til sammen med Kirkeligt Samfund og Grundtvig-Selskabet. Tre seminarer har været afholdt, og et er planlagt. Den 10. marts 2007 blev der på Den frie Lærerskole i Ollerup, Sydfyn, afholdt et indledende seminar om "Grundtvig og skolen". Her talte K. E. Bugge ("Nogle grundbegreber i N. F. S. Grundtvigs pædagogiske tanker"), Ove Korsgaard ("Det nødvendige $i$ at inddrage N. F. S. Grundtvigs skolesyn i en nutidig debat om skolen og dens rolle i samfundet"), Torsten Johannessen ("Noget andet og mere end en skole: Om den grundtvig-koldske friskoletradition og dens nutidige stærke vækst"), Uffe Raahede ("Det gælder ikke alene håndens og åndens, men også hjertets dannelse: Efterskolen og dens inspiration fra N. F. S. Grundtvig”), Jørgen Carlsen ("At være sig selv, men ikke sig selv nok. N. F. S. Grundtvigs bidrag til en nutidig forståelse af forholdet mellem individ og fællesskab") og Jørgen Gleerup ("Dannelse og selvdannelse: Den moderne krise i 
pædagogikken og muligheden for at bruge Grundtvig som løsningsmodel"). Næste seminar blev afholdt den 2. juni 2007 i Vartov, København, med overskriften "Grundtvig og teologien". Her talte Henrik Wigh-Poulsen ("Grundtvig og det religiøse"), Hans Raun Iversen ("Grundtvig og det universelle"), Hans Gammeltoft-Hansen ("Grundtvig og folkekirken"), Morten Kvist ("Grundtvig og gudstjenesten") og Inge Lise Pedersen ("Grundtvig og menigheden"). Det tredje seminar om "Grundtvig og det politiske" blev afholdt den 24. august 2007 på Aarhus Universitet. Her talte Thorkild C. Lyby ("Grundtvig som politiker efter 1849"), Harry Haue ("De folkelige bevægelser som samfundsfaktor i 2. halvdel af det 19. århundrede"), Inge Adriansen ("Grundtvigsk islæt i den nationale symbolik"), Jes Fabricius Møller ("Splittelse i den grundtvigske lejr i tiden omkring de to verdenskrige"), og Dag Thorkildsen ("Grundtvigianismen som folkelig og national faktor i Norge").

Sideløbende med de fire orienteringsseminarer foregår der et intensivt arbejde med at forberede den digitale Grundtvig-udgave. Kim Arne Pedersen er fortsat ansat som deltids udredningsmedarbejder. Udgivelsens styregruppe, der har Jens Holger Schjørring som formand, har holdt jævnlige møder og er nået langt $\mathrm{i}$ retning af at udarbejde principper for udgivelsen, ligesom der er taget skridt til at søge offentlige og private fonde om støtte til projektet.

Oversættelsesprojektet Grundtvig på tysk, gennem mange år dygtigt, sagkyndigt og målrettet ledet af K. E. Bugge, Theodor Jørgensen og Flemming Lundgreen-Nielsen, står nu over for udgivelse.

Grundtvig-Biblioteket i Vartov under ledelse af bibliotekar Liselotte Larsen er fortsat en nyttig, for mange uundværlig, hjælp i grnndtvigstudiet, og Vartov-Arkivet for Grundtvigs pædagogiske virkningshistorie, også i Vartov, er ligeledes ved at blive et centralt studieog forskningscenter.

Vartovbogen, der udgives af Kirkeligt Samfund, har i år (2007) samlet artikler om "Menneskesyn i skole- og arbejdsliv" af Anna Maria Holm, Arne Ørtved, Kirsten M. Andersen, Uffe Raahede, Frederik Dreiøe Seidelin, Lærke Grandjean, Kirsten Marie Bovbjerg, Bjørg Tulinius, Christian Kock, Dorthe Jørgensen, Klaus Nielsen, Jan Lindhardt og Henning Nielsen.

Igen $\mathrm{i}$ år skal der på Grundtvig-Selskabets årsmøde lyde en tak til alle, der på forskellig vis har hjulpet selskabet i årets løb. Ansatte på Center for Grundtvigstudier ved Aarhus Universitet, på GrundtvigAkademiet, Grundtvig-Biblioteket og Vartov-Arkivet i København. Dertil kommer Kirkeligt Samfund repræsenteret ved formanden, Jens Bruun, og sekretariatsleder i Vartov, Hans Grishauge, sammen med sekretær Kirsten Grishauge. Forskningsrådet for Kultur og Kommuni- 
kation skal takkes for støtte til udgivelsen af Grundtvig-Studier, og alle medlemmer af Grundtvig-Selskabet i Danmark og Norge og i udlandet i øvrigt skal takkes for en usvækket interesse for og støtte til Grundtvig-Selskabets arbejde for "studiet af N. F. S. Grundtvig, hans virke og hans stilling i åndslivet i og uden for Danmark". 